\title{
МЕТОДИЧНІ ОСНОВИ ФОРМУВАННЯ ЖИТТЕВОЇ КОМПЕТЕНТНОСТІ ВИПУСКНИКІВ ЗАГАЛЬНООСВІТНІХ ШКІЛ-ІНТЕРНАТІВ
}

Яковлєва В. А. Методичні основи формування життєвої компетентності випускників загальноосвітніх шкіл-інтернатів.

У статті розкрито можливості формування життєвої компетентності випускників загальноосвітніх шкіл-інтернатів за допомогою профільного навчання. Профільное навчання розглядається з позииї інтерактивної технологї. Розкривають умови інтеракиії учнів у прочесі профільного навчання.

Ключові слова: компетентність, життєва компетентність, інтерактивні технології, профільне навчання, випускники шкіл-інтернатів.

Яковлева В.А. Методические основы формирования жизненной компетентности выпускников общеобразовательных школ-интернатов.

В статье раскрыты возможности формирования жизненной компетентности выпускников общеобразовательных школ-интернатов посредством профильного обучения. Профильное обучение рассматривается с позищии интерактивной технологии. Определень условия интеракиии учащихся в прочессе профильного обучения.

Ключевые слова: компетентность, жизненная компетентность, интерактивные технологии, профильное обучение, выпускники школ-интернатов.

Yakovleva V. Methodological foundations of life competencies graduates of boarding schools.

In the article refers to the possibility of forming life competence graduates of boarding schools by means of special training. Special training is presented as a interaction technology.

Key words: competence, life competence, interactive technology, specialized education, graduates of boarding schools.

Постановка проблеми. Майбутнє України за поколінням, яке нині опановує освіту, якість якої залежить від рівня сформованості його життєвої компетентності. Українське суспільство, його професійна сфера, очікують спеціалістів, які ефективно включатимуться в розробку й реалізацію різноманітних проектів та технологій, виявлятимуть готовність до розв'язання проблем, розробки нових ідей, особисту зацікавленість в підвищенні ефективності праці тощо.

Для гармонійної взаємодії та успішної життєдіяльності у швидко прогресуючому суспільстві, людині необхідні якісно нові знання, вміння, навички і навіть риси характеру. Це, в свою чергу, вимагає докорінного реформування змісту освіти, навчання та виховання дітей в різних суспільних інститутах. У контексті цього, європейські країни передбачають трансформацію знань, умінь і навичок, набутих дітьми та молоддю в процесі навчання та виховання, у компетентність. Актуальність розгляду компетентності як мети освітньо-виховного процесу та розробки відповідних програм по іiі формуванню підкреслюється сучасним соціальним фоном: наша країна одночасно крокує шляхом від диктатури до демократії, від 
соціалізму до капіталізму, від організованого суспільства до суспільства ризику Тому роль і значення компетентності, за визначенням В. Ягупова, корелює не лише 3 життєдіяльністю конкретної людини (iї вірою в себе й ефективністю функціонування), але і 3 вимогами проблемної соціальної ситуації, яку необхідно розв'язати[5, с. 9].

Аналіз ситуації стосовно випускників загальноосвітніх інтернатних закладів дозволяє визнати, що виховання в цих закладах забезпечує лише певною мірою безпроблемне існування у подальшому житті. Проблема пристосування їх до нового соціуму у зв’язку з кризовою ситуацією в країні значно ускладнюється: випускники державних інтернатних закладів не витримують конкуренції спочатку на рівні професійної та вищої школи, а згодом і на ринку праці.

Тому виникає потреба оновлення навчального процесу в загальноосвітніх школах-інтернатахі одним із важливих напрямів цього процесу визначається компетентнісний підхід.

Відповідно до теми нашого дослідження, 3-поміж усіх компетентностей виокремлено життєву компетентність особистості.

За визначенням Н. Бібік, «компетентність людини - це загальна життєздатність, що базується на знаннях; досвіді, ціннісних орієнтаціях, здібностях тощо» [1, с.408]. Звідси, життєву компетенцію будемо розглядати як чинник та результат розвитку життєдіяльності особистості.

Нам також імпонує думка науковців I. Єрмакова та Г. Несена, які розглядають життєву компетентність, як якість особистості, що формується під час міжособистісної взаємодії, спілкування, без якого неможливе іiі становлення [2, с.113].

Результати досліджень надають змогу констатувати, що одним iз ефективних засобів формування основ життєвої компетентності випускників загальноосвітніх інтернатних закладів є створення умов для інтеракції учнів у процесі профільного навчання.

Профільне навчання як інтерактивна технологія є засобом диференціації та індивідуалізації навчання, коли за рахунок змін у структурі, змісті та організації освітнього процесу більш повно враховуються інтереси, схильності і здібності учнів, створюються умови для діяльності учнів випускних класів відповідно до їх професійних інтересів та намірів щодо продовження освіти. Профільне навчання спрямоване на реалізацію особистісно-орієнтованого навчального процесу. При цьому, істотно розширюються можливості вибудовування учнем власної, індивідуальної освітньої траєкторії.

Проаналізувавши психолого-педагогічну літературу, ми зупинилися на суті інтерактивного навчання. А саме: «...сутність інтерактивного навчання полягає в тому, що навчальний процес відбувається тільки завдяки постійній, активній взаємодії всіх учнів. Це співнавчання, взаємонавчання (колективне, групове, навчання у співпраці), де й учень, i вчитель $є$ рівноправними, рівнозначними суб'єктами навчання і розуміють, що вони роблять, рефлексують з приводу того, що знають, уміють і здійснюють [4]. 
Спілкуючись 3 однолітками, у процесі профільного навчання як інтерактивній технології,учні вчаться адекватно й доречно користуватися мовою в конкретних ситуаціях, володіти собою, мистецтвом переживань; керувати психічним станом, тілом, голосом, мімікою; настроєм, думками, почуттями; знімати м'язові затиски. У них відбувається розвиток умінь розв'язувати моральні задачі, що випливає із вікових та психологічних особливостей учнів даного віку [4, с.112].

Аналіз досліджень свідчить, що в умовах профільного навчання стає можливим розвиток особистості, здатної визнавати і поважати цінності іншої людини; розвиток навичок спілкування та співпраці з іншими членами групи (суспільства); взаєморозуміння та взаємоповаги до кожного індивідуума; виховання якостей: толерантності, співчуття, доброзичливості та піклування, почуття солідарності й рівності; формування загальнолюдських цінностей та загальноприйнятих норм поведінки; вміння об'єднуватися з іншими членами суспільства задля розв'язання спільної проблеми; вміння робити вільний та незалежний вибір, що грунтується на власних судженнях та аналізі дійсності; розуміння норм і правил поведінки в суспільстві та поваги до них; знання законів, основних прав людини; особистої відповідальності та громадянського обов’язку; здатності цінувати свободу та вміння користуватися нею; усвідомлення особистої відповідальності.

Взаємодія в умовах профільного навчання $\epsilon$ як специфічний вид діяльності 3 «обробки» людей людьми. У процесі спілкування людина «опредметнює» свої суттєві сили в інших людях, утверджуючись як член людського суспільства. I в тому ж процесі проходить «розпредмечування», засвоєння накопиченого людського досвіду. При цьому проходить процес формування власного «Я» людини, становлення iii як особистості, ii життєвих ціннісних орієнтацій [2].

Профільне навчання $\epsilon$ ареною для самоствердження випускників загальноосвітніх шкіл-інтернатів. Вони сприяють формуванню у підростаючої особистості соціально-когнітивного компоненту життєвої компетентності. За умов такого навчання, учні отримують основи знань про норми взаємодії в суспільстві, розвиток уміння будувати нові взаємовідносини; виховання миролюбності, гуманності, альтруїзму, ознайомлення 3 власним «Я», визначення в собі позитивних та негативних рис. В учнів-випускників формується фундамент громадянської позиції, політичного мислення; готовність до використання знань як інструмента розв'язання життєвих проблем, аналізу нестандартних ситуацій.

У процесі профільного навчання розвиваються та ускладнюються психічні процеси - сприймання, пам'ять, увага, уява тощо; забезпечується формування таких інтелектуальних умінь, як аналізувати, порівнювати, виокремлювати головне, а на основі цього критично мислити та приймати відповідальні рішення. Перебуваючи постійно у стані змін міжособистісних зв'язків, кожен учень своєрідно переживає когнітивну ситуацію, а разом із тим психологічну і соціальну. Вони вчаться співпрацювати і досягати спільних цілей. 
Виконуючи спільне завдання, учень усвідомлює свою важливість у колективі, виявляє свою ініціативу, самостійність, лідерські якості, вміння працювати в колективі, беручи до уваги інтереси інших. За правильної організації, учні у процесі профільного навчання отримують практичні навички повсякденного громадянського досвіду: партнерства та взаєморозуміння, лідерства та поваги до інших, ініціативності у прийнятті рішень, висловлюванні думок, практики відповідальності за реалізацію індивідуальних і колективних справ.

За умов інтеракції учень вчиться робити свідомий вибір серед широкого спектру альтернатив і брати на себе відповідальність приймати самостійні рішення.

Нині відчувається недостатність науково-методичних рекомендацій із проблем профільного навчання випускників загальноосвітніх шкілінтернатів, використання яких впливає на практичну діяльність колективів навчальних закладів. Тому одне з головних завдань профільного навчання в школі $є$ формування в людині найкращих якостей особистості, надання учням творчого спрямування у вирішенні будь-яких технологічних завдань.

Значення профільного навчання важко переоцінити і в освітньому, і в професійному відношенні. Ось як визначає його значення О. Коберник: «Новий зміст i структура профільного навчання потребує певного переосмислення організації та методики занять стосовно проектнотехнологічного підходу» [3, с. 2].

Однією з перспективних можливостей профільного навчання учнів випускних класів $є$ розвиток творчої особистості в системі методів проектних технологій.

Розглядаючи вимоги до підбору об'єктів проектування, ми вважаємо, що заняття 3 профільного навчання мають бути побудовані на засадах організації проектної діяльності школярів. Проектно-технологічні знання базуються на технологічних поняттях, оскільки вони сприяють розумінню сутності творчого проекту. За їх допомогою розкриваються вимоги до виконання проекту, створюються умови для успішного вивчення властивостей матеріалів, які повинні використовуватися під час розроблення проектів.

Проектно-технологічні знання учнів повинні носити системний, цілісний характер і повинні здобуватися в процесі вивчення різних шкільних дисциплін, які викладаються в конкретному класі. На базі них повинні розроблятися проекти та інша технологічна документація, що необхідна для виготовлення проекту.

Основні якості особистості, які формуються в процесі проектнотехнологічної діяльності учнів такі: техніко-конструкторський світогляд $\mathrm{i}$ технічне мислення, свідоме та відповідальне ставлення до навчання і праці, прагнення до самоосвіти, розвиток фантазії і уяви, сформоване відчуття краси, самостійність, працьовитість, естетичний та художній смак, культура праці тощо. Робота над проектом сприяє особистісно-орієнтовному навчанню школярів в процесі освоєння певного профілю з урахуванням їх 
інтересів. Створюються умови інтенсивного розвитку творчої пізнавальної активності учнів в процесі розробки проектів. Підбираючи об'єкти праці, необхідно звертати увагу, в першу чергу, на можливість їх удосконалення.

Одним 3 найбільш ефективних активних методів профільного навчання можна назвати метод розробки творчих проектів, заснований на конструюванні мультимедіа ресурсів самими учнями. Серед безлічі цілей побудови та використання мультимедійних ресурсів у системі профільного навчання можна виокремити дві основні групи:

- формування в учнів технологічних умінь роботи 3 сучасними телекомунікаційними середовищами;

- формування інтелектуальних інформаційних умінь.

Мультимедіа - це подання об’єктів і процесів не традиційним текстовим описом, але за допомогою фото, відео, графіки, анімації, звуку, тобто у всіх відомих нині формах. Тут ми маємо дві основні переваги якісну і кількісну.

Якісно нові можливості очевидні, якщо порівняти словесні описи 3 безпосереднім аудіовізуальним поданням. Кількісні переваги виражаються в тому, що одна сторінка тексту, як відомо, містить близько 2 Кбайт інформації. Викладач промовляє цей текст приблизно протягом 1-2 хвилин. За ту ж хвилину повноекранне відео переносить близько 1,2 Гбайт інформації. Ось чому «краще один раз побачити, ніж мільйон разів почути». Методика використання мультимедійних технологій передбачає:

- удосконалення системи управління навчанням на різних етапах уроку;

- посилення мотивації навчання;

- поліпшення якості навчання i виховання, що підвищить інформаційну культуру учнів;

- підвищення рівня підготовки учнів в області сучасних інформаційних технологій;

- демонстрацію можливостей комп'ютера, не тільки як засобу для гри.

Мультимедійні уроки допомагають розв'язати такі дидактичні завдання:

- засвоїти базові знання з предмета;

- систематизувати засвоєні знання;

- сформувати навички самоконтролю;

- сформувати мотивацію до навчання в цілому і до інформатики зокрема;

- надати навчально-методичну допомогу учням у самостійній роботі над навчальним матеріалом.

Цю технологію можна розглядати як пояснювально-ілюстративний метод навчання, основним призначенням якого $\epsilon$ організація засвоєння учнями інформації шляхом повідомлення навчального матеріалу та забезпечення його успішного сприйняття, яке посилюється при підключенні зорової пам’яті. Відомо (дослідження інституту «Евролінгвіст», Голландія), що більшість людей запам'ятовує 5\% почутого і 20\% побаченого. Одночасне використання аудіо-та відеоінформації підвищує запам'ятовування до 4050\%. Мультимедіа програми подають інформацію в різних формах i тим 
самим роблять процес навчання більш ефективним. Економія часу, необхідного для вивчення конкретного матеріалу, в середньому становить 30\%, а набуті знання зберігаються в пам’яті значно довше.

Під час використання на уроці мультимедійних технологій структура уроку принципово не змінюється. У ньому, як і раніше, зберігаються всі основні етапи, зміняться, можливо, тільки їх тимчасові характеристики. Необхідно відзначити, що етап мотивації в даному випадку збільшується і несе пізнавальне навантаження. Це необхідна умова успішності навчання, так як без інтересу до поповнення знань, яких бракує, без уяви і емоцій немислима творча діяльність учнів.

Підсумовуючи сказане, можна зробити висновок, що у процесі інтеракції учнів засобами профільного навчання створюються ефективні умови для комплексного формування життєвої компетентності випускників загальноосвітніх шкіл-інтернатів.

\section{Література}

1. Бібік Н.М. Компетентність у навчанні / Н.М. Бібік // Енциклопедія освіти: АПН України; гол. ред. В.Г. Кремень. - К.: Юрінком Інтер, 2008. - С. 408-409.

2. Срмаков І.Г. Формування життєвої компетентності учнів шкіл-інтернатів у контексті комплексної реабілітації: орієнтири до прогностичного експерименту/ І.Г. Єрмаков, Г. М. Несен // Реабілітаційна педагогіка на рубежі XXI століття : [наук.-метод. зб.] у 2-х частинах; ред. рада: В.М. Доній, Г.М. Несен, І.Г. Срмаков та ін. - К. : ІЗМН, 1998. - Ч.2. - С. 113-21.

3. Коберник О.М. Урок трудового навчання в умовах проектно-технологічної системи / О.М.Коберник // Трудова підготовка в закладах освіти. - 2006. - №1. - С.2-5.

4. Освітні технології : [навч.-метод.посіб.] / О.М.Пєхота, А.З.Кіктенко та ін. - К. : A.C.K., 2001. - $256 \mathrm{c}$.

5. Ягупов В.В.Професійна компетентність випускників системи професійнотехнічної освіти / В.В. Ягупов // Система роботи ПТНЗ з формування професійно мобільного кваліфікованого робітника. Матеріали Всеукраїнської науково-практичної конференції (м. Кривий Ріг, 23-24 листопада 2011 р.). - Кривий Ріг: Ін-т ПТО НАМН України, 2011. - С.9-11.

Стаття надійшла до редакції 30.05.2012 p.

УДК 371.134

I. С. Вдовенко, кандидат пед. наук, доиент, Чернігівський наџіональний педагогічний університет імені Т.Г. Шевченка

\section{ЗАСТОСУВАННЯ ЗМАГАЛЬНИХ ІНФОРМАЦІЙНИХ ТЕХНОЛОГІЙ У НАВЧАЛЬНОМУ ПРОЦЕСІ ПРОФЕСІЙНО-ТЕХНІЧНИХ НАВЧАЛЬНИХ ЗАКЛАДІВ}

Вдовенко I. С. Застосування змагальних інформаиійних технологій у навчальному проиесі професійно-технічних навчальних закладів.

У иій статті розглянуто застосування новітніх інформаційний технологій у навчальному процесі професійно-технічних навчальних закладів.

Ключові слова: змагальні інформачійні технологї̈, навчальний прочес, професійнотехнічні навчальні заклади. 